This article is available open access under a CC BY-ND 4.0 license as part of Berghahn Open Anthro, a subscribe-to-open model for APC-free open access made possible by the journal's subscribers.

\title{
Sovereignty, Prefigurative Politics, AND BASQUES' JOY TO DECIDE
}

Julieta Gaztañaga

\begin{abstract}
The literature about Basque politics and the anthropology of sovereignty often define the political within the boundaries of violence, desire, and statehood: a sort of pessimism pervades the general assumptions and the end results. In this article, I shift the focus to a different aspect of the problem of sovereignty, drawing on ethnographic research about a Basque social movement that asserts self-determination in terms of a democratic and pacifist 'Right to Decide'. Exploring the movement's organization, daily activities, performances, sociality, and discourses, I argue that they prefigure political pleasure in a way that encourages the performance of sovereignty as a positive force. I show how the movement creates an environment in which producing sovereignty becomes a joyful experience.
\end{abstract}

Keywords: Basque Country, ethnography, political anthropology, political pleasure, social movements, sovereignty

Gure Esku Dago (GED), in English "It's in our hands," is a social movement fighting for the independence of the Basque Country. It was launched in 2013, building on a long history of local grassroots mobilizations for the right to self-determination, or what is locally debated as the people's 'Right to Decide' (RtD). GED has been recentering the old nationalist dilemma of independence as secessionism, separatism, or confederation in terms of the principle and praxis of 'popular sovereignty' with the clear political goal of showing that Basques are in favor of deciding their political future, a right ultimately leading to a referendum.

GED activists tend to have a frantic agenda packed with meetings, workshops, talks, public performances, demonstrations, and the organization of hundreds of 'popular consultations' (herri galdeketak)-local events similar to 
a referendum meant as opportunities to train the 'democratic muscle' required for voting in a future official referendum. These activities are always organized in a way to make them enjoyable by spending good moments with others. The joyful symbolism of these public activities (singing songs, dancing, hanging colorful banners), in the presence of children and families, is aimed to gain public attention and to produce social engagement with the movement. The ultimate goal is to reframe the 'right to self-determination' in terms of positive values, such as peace, democracy, solidarity, dignity, horizontality, and popular will, rather than the association with armed struggle.

Notwithstanding this plethora of actions, when I arrived to do fieldwork with my friends and acquaintances in Donostia-San Sebastián, the capital city of the Basque province of Gipuzkoa, most of them had left. It was 30 September 2017, and the Catalans were holding an independence referendum the next day. "I couldn't miss such a historical moment," "I went to help," "It was both sad and familiar to see the Spanish riot police beating people," they explained to me later. I asked whether they were afraid of exposing themselves to such violence. "No, we are familiar with the government's violence," many replied. In this case, the referendum ended with the imprisonment and exile of many Catalan leaders and the imposition of direct rule from Madrid. I began to wonder what the meaning of claiming a right to decide could be in a social milieu pervaded with the consequences of the old patriotic battle cry "liberty or death" associated with Euskadi ta Azkatasuna (ETA, or Basque Homeland and Liberty), and to what extent such traumatic experiences could be a key component of GED's joyful orientation within the post-ETA context.

In contrast to the right to 'decision', the experience of self-determination is mirrored by the unceasing violence of the Spanish authorities against independentists. My Basque friends had many stories to tell about this. I remember one in particular provided by Anjel, GED's spokesman and a leading figure of Nazioen Mundua, a social movement launched in 2007, six years before GED and now subsumed into the latter. We were having lunch at a fancy Japanese restaurant, mixing Spanish and Euskara and switching between topics, such as sixteenth-century whale hunters, organic food, Basque international companies, the Scottish referendum, the parliamentary motion in Québec, and the Catalan process. He asked me if I had ever heard about "The Ring":

Anjel: At schools until about 40 years ago there was The Ring.

JG: An actual ring?

A: Well it was a 'game', in quotes of course. Children didn't know Spanish, but they knew their language, Euskara. The teachers came from outside and taught Spain's unitary regime. When the teacher heard a student speaking Euskara, he would give the ring to this student. And then what? If this child heard another one ... [he dramatizes:] Hey teacher, this one here 
speaks Basque! ... Then the teacher would pass the ring on to that one. At the end of the day, the kid who had the ring: the cane [makes the gesture of beating]. This system was exported to other countries, but it's Spanish ...

JG: They encouraged fear and mutual denunciation, right?

A: Sure, and who wants to belong to that community? This is why so many parents have not transmitted the language, because if you love your kids you do not want troubles for them.

JG: It is so sad ...

A: Well, but so many things happened here, Franco was the last one. We got Empires, wars, famines. And yet we persist: here we are speaking Euskara.

Scholars examining political processes concerning self-determination in stateless nations tend to address questions of political subjectivities and political authority as issues of nationalism within a wider conceptual constellation of forms of identity and diverse ways of establishing borders and boundaries. This has been the case for the study of Basque politics, in which the issue of sovereignty is rarely addressed, contrasting with an extensive attention paid to secessionism, separatism, and self-determination. In this article, I suggest that current debates of political anthropology that focus on "exploring de facto sovereignty, i.e., the ability to kill, punish, and discipline with impunity wherever it is found and practiced, rather than sovereignty grounded in formal ideologies of rule and legality" (Hansen and Stepputat 2006: 296) could enrich the study of contemporary Basque politics. Theoretically and methodologically promising, such an approach to 'sovereignty-in-practice' allows one to bypass the taken-for-granted link between state desire and armed struggle. However, ethnographies of de facto sovereignty tend to be similarly focused on the connection between authority and violence, revealing a somewhat misanthropic view of politics and human nature. Drawing from my ethnography with the members of GED, I offer a complementary approach to understanding sovereigntyin-practice-one that is centered on political pleasure, or the 'politics of joy'.

In the first section, I examine anthropological scholarship that defines sovereign power as a tentative and unstable project whose efficacy and legitimacy depend on repeated performances of violence and a "will to rule" (Hansen and Stepputat 2005: 3). I argue that this endeavor is key to destabilizing formal and legal notions of sovereignty and hence might help to break with the ubiquity of nationalism and violence that characterizes most literature about Basque politics. However, because most ethnographies of 'practical sovereignty' are oriented to post-colonial settings and underlying assumptions of informal authority, there are some constraints in providing a productive perspective of politics. Exploring the possibilities of incorporating political pleasure in the examination of practical sovereignty, in the second section I propose that the 'right to decide' is actually experienced as the 'joy of deciding'. Taking my lead 
from the ethnography of GED, I analyze the daily activities and forms of sociality that create possibilities to enjoy sovereignty-in-practice. In the third section I develop this argument by examining a central concept around which GED's everyday politics pivots, namely, saretzea. Saretzea (lit., 'making nets') is a form of 'prefigurative politics' whereby people transform the negative memories of the past into something positive, thus producing subjectivities that enjoy politics and view sovereignty as a positive force.

This article is the result of eight months of intensive ethnographic fieldwork carried out among the members of different local-level groups of GED, and particularly of the Donostia group, between October 2017 and November 2018. I participated in their daily routine of meetings, took part in large events and press conferences, helped with the logistic of certain events, prepared speeches, assisted with translations, and acted as an international observer (begirale) for two consultations. I was allowed to witness and help with the entire process of building consensus toward deciding to hold a popular consultation and the everyday political work that was necessary to achieve it. I also made friends, spent many evenings at local pubs, shared family and communal meals, went on short journeys, walks, and visits to cafés, and was able to share daily chats and laughter.

\section{Sovereignty beyond Armed Struggle and State Desire}

Most of the literature about Basque politics-historical and contemporaryputs violence center stage and pivots around a "desire for statehood" (Aretxaga 2003: 394). Whether focusing on the latest armed conflict or not, self-determination claims are thus linked to topics such as primordial identity, ethno-politics, chronic violence, diaspora, and memory (e.g., Aretxaga 1988; Douglass 1985; Elorza 2001; Ibarra 2005; Juaristi 1987; Rodriguez Bornaetxea 2011; Vilaregut et al. 2014; Zulaika 1996). The issue of sovereignty is rarely addressed except when referring to self-determination claims as secessionism. The difficulty of imagining Basque politics without thinking of Spanish repression and violent resistance was recognized even by those Basque anthropologists (Aretxaga 2003; Zulaika 2007; Zulaika and Douglass 1996) who produce the most rich and nuanced cultural analysis of Basque nationalism and its complex articulations with religion, ritual, kinship, gender, the body symbolism, and the contradictory dynamics of terrorism.

Despite its complex historical formation in a time of major economic and social change provoked by rapid industrialization, Basque nationalism has also been subject to stereotypical comments on its supposed extremist nature. ${ }^{1}$ Travel guidebooks, journalists, food connoisseurs, artists, and academics often present Basques as an anomaly in the course of history, isolated, rustic, 
stubbornly determined in preserving their identity, with 'primitive' customs and language. Unrelated to other neighboring languages, Euskara is part of this romantic narrative-a 'survival', a living piece of archaeology that is now regaining speakers after a contraction of nine centuries. During my fieldwork, I was reminded many times about how difficult is to escape from these views that pervade Basque politics. As one of my interlocutors put it: "If one tries to understand ETA, one becomes like an anthropologist who studies cannibalism and is accused of eating people"

There has been a totalizing operation to characterize the Basque world as being shaped by experiences of direct and subtle confrontations between Spain and ETA. When I visited my Catalan friends after the October 2017 referendum, they were shocked by the police brutality: "This is outrageous, we are not like the Basques. We are pacifists!" I commented on this to my Basque friends, and they just frowned. Most consider that although the end of the armed struggle has been a major step toward solving local violence, the conflict remains because the democratic Spanish transition that commenced in 1978 is not yet accomplished. They see violence as a defining feature not of Basque politics or identity, but of Spain, expressed by Franco's dictatorship (1939-1975), the Spanish Civil War (1936-1939), the Carlist Wars (1833-1876), the Spanish Inquisition, and the extensive colonialism in America, the Philippines, and the Western Sahara.

Nation-statist views in public opinion and academic work produce for my interlocutors an omnipresent relationship between armed struggle and the desire for statehood, banning people from the possibility of imagining themselves outside a dreaded cycle of terror and violence. The very definition of the Basque Country as a 'stateless nation' naturalizes the administrative perspective of the nation-state and its "unifying pabulum" (Herzfeld 1991: 80), and thus prevents further examinations of the "untenable hyphen" (Aretxaga 2003: 396) between nation and state. For instance, most inhabitants of the Basque Country have supported the idea of self-determination for decades, although most of them did not see it as independence (Moral 1998). What is more, such reductive characterizations seem to underestimate that after a half-century of armed struggle and state repression, the Basque Country has undergone substantive changes, among them a growing social desire for peace and democratic co-existence. It is now a tourist destination with an exquisite cuisine awarded with Michelin stars, a manufacturing economy identified with innovation, a strong finance and banking location, and a home for art and architecture. There is a relative consensus that this 'success' has to do with the combination of at least three elements. The first is the so-called peace process that started in 2009 and ended in April 2018 when ETA completely dissolved all its structures and ended its political initiative. The second element is the participation of the pro-independence left in parliamentary life after decades of illegalization, the imprisonment of its leaders and militants, clandestine activity, and a systematic refusal to take part in institutional 
politics. Since 2011, a change of strategy led to the creation of the Euskal HerriaBildu (EH-B, or Basque Country-Reunite) coalition, which became a second force in the Basque Parliament after the National Basque Party (EAJ-PNV). The third element is the relative success of the Basque Economic Agreement, ${ }^{2}$ which regulates the relations between the General Administration of the Kingdom of Spain and the Autonomous Community of the Basque Country.

Focusing on sovereignty instead of nationalism allows us to paint a more complex picture of contemporary Basque politics where the right to decide represents an innovation vis-à-vis self-determination rights. This shift is also faithful to the transformation of the use of the term 'sovereignty' in Spain-from the generalized rejection of the term by regional nationalists against a Francoist totalitarian state until the late 1980s, to its adoption alongside citizenship in the context of a "Europe of the Peoples" (Aretxaga 2005: 138-139).

The so-called modern anthropological approach to sovereignty was developed after a seminal redefinition of the concept by Hansen and Stepputat (2006: 297), who see sovereignty as "a tentative and always emergent form of authority grounded in violence that is performed and designed to generate loyalty, fear, and legitimacy from the neighborhood to the summit of the state." The studies of the de facto workings of sovereignty have been nourished by empirical questions of what authority and force look like and act like, producing detailed examinations of the potential for lethal violence that haunts the banal and quotidian. This sort of sovereignty-in-practice approach denaturalizes the unitary, ideal-type, and transcendental embodiments of who wields the power to decide over life and death, as in Agamben's (1998) formulation, and points out the proximity between lawmaking and lethal violence, as in Benjamin's (1978) distinction between lawmaking and law-preserving. This approach is also methodologically appealing as it allows ethnographic comparisons of the basic mechanisms that make sovereign powers effective although fragile, tentative, and unachieved. It integrates diverse efforts to unveil categories of Western political thought (Trouillot 2003) and study forms of discipline and governance in the context of globalization and the so-called crisis of the nation-state (Hansen and Stepputat 2005; Kauanui 2017). ${ }^{3}$

Social movements like GED fit well with the idea of de facto or in-practice sovereignty because they are engaged in political experimentation that furthers the various uses, negotiations, and contortions of the concept of sovereignty that do not meet its Westphalian ideal. However, I find two interrelated problems with the approach to sovereignty-in-practice. On the one hand, it privileges the performance of violence. Ethnographies of sovereignty-in-practice focus on topics such as warfare, militarism, surveillance, illegal networks, and biopolitics, even when they examine how people struggle to enact sovereignty (e.g., Moreton-Robinson 2007; Rifkin 2012) and the subjectivities of those who reside in 'spaces of exception', such as refugee camps, borderlands, or war zones 
(e.g., Comaroff and Comaroff 2016; Fassin and Pandolfi 2010). Considering the Basque case, this is not very helpful if we wish to break with the social orders that the ubiquity of violence and the desire for statehood enable and disavow.

On the other hand, there seems to be a tension between the nature of ethnographic inquiry - which renders particular performances of power contingent, contestable, and analyzable-and sovereignty as an abstract legal concept where national-state war and security regimes remain at the center. Even though ethnographies make clear that their focus is all about local, everyday matters, they share a tendency to assume what philosophers believed about the state of exception as an expression of sovereignty, which already implies that it exists. Perhaps this has to do with the fact that modern anthropology of sovereignty is grounded on a critique of the founding fathers of political anthropology who apparently "failed to provide an adequate matrix for understanding the political imaginations of a world after colonialism" (Hansen and Stepputat 2006: 297). However, the modern approach has taken up Agamben's re-evaluation of Foucault's developments on the transformation in the exercise of sovereign power (Hansen and Stepputat 2005; Humphrey 2004), which in turn furthers Foucault's concept of biopower to propose sovereign power as the capacity to bear rights through exclusion (Agamben 1998). In sum, the classic model of political sovereignty has become reinscribed as an actually existing relationship (Bonilla 2017: 332). ${ }^{4}$

It seems that questioning understandings of sovereignty as an ontological ground of power and order-a proposal of a more complex and unsettled configuration of sovereignty-has assumed an approach that combines sovereign violence and the Schmittean analysis of politics as the distinction between friend and foe. By contrast, GED people who fight for self-determination also experience sovereignty as a joyful praxis. Their project is not designed to produce laws or enduring ideas of legitimate rule; instead, their goal is to exercise popular sovereignty, ultimately expressed in a referendum. It became clear that I ought to question how to think positively and productively about the politics of sovereignty and to analyze joy as a productive political force instead of a marginal anecdotal element of the way people fight for and figure sovereignty. In light of the above-mentioned anthropological discussions, in the next section I will examine GED's sovereignty-in-practice in order to answer the question, what about the joy of the right to decide?

\section{Joy to Decide}

Up to the present, GED has organized more than 200 popular consultations in small villages and cities. According to GED's website, this non-official voting is regarded as an educational resource that aims to "deepen democratic culture" 
by "focusing on citizen participation and empowerment." ${ }^{5}$ GED often places the right to decide in opposition to the right to vote by stressing that a majority vote always produces losers. As I will show shortly, the Right to Decide (RtD) is not meant to empower an abstract 'people', nor does it embody the theoretical concept of sovereignty since it does not necessarily involve a call for independence. GED members, and particularly their 'organic intellectuals' (Gramsci 1972), describe it variously as a new democratic "political paradigm," a "common ground to reflect" on new trends about the right to self-determination, a "postmodern concept" in tune with an "evolution" of juridical tools, and so forth. Some even frame it into citizenship visions of a renewed class struggle that retakes the old Marxist "Basque working people."

GED's plea for the RtD could be seen to foster 'governmentality' and taking part in the production of a citizenship regime that would create citizens with moral, political, and economic attributes (Foucault 2003). However, their understandings of a democratic demos are closer to a post-Leninist 'multitude' (Hardt and Negri 2004) and influenced by 'popular struggle' and hegemony (Laclau 2008), and Thoreauvian civil disobedience. GED's sovereignty-in-practice seeks to disentangle the link between the subject and the object of decision as presented in the self-determination frame. As one interlocutor put it: "The right to decide sounds silly if you think democracy itself is already such a right. Even worse, it seems we have taken a step back, surrendering an already internationally recognized right of self-determination. But we have taken a step forward.” Another clarified the RtD with regard to GED's fostering of internal heterogeneity as a positive value: "Before, the object of self-determination was predefined (independence was equal to secession), but the subject (demos) posed too many problems. Instead, we depart from the latter. It is the demos, the people, the voting personae who decide the former." To distinguish 'independence' from 'secession' is important, given the fact that the RtD does not seek to reproduce neoliberal individuality nor old Marxist vanguardism.

In many respects, GED shares some key political values and features with the Indignados mass movement assemblies in Spain and the international Occupy movement, for example, horizontalism as the practice of non-representational and non-hierarchical politics and consensus-based decision making by way of a general assembly. There are also differences since GED has a General Secretariat (Idazkaritza), which plays a leading role in proposing ideas and suggesting new paths of action. Some members of local groups see this as a negative feature for it makes decision-making processes hierarchical, intrusive, and opaque; but generally speaking they credit the Idazkaritza positively. Its proposals have to do with the everyday functioning of the movement, such as putting an end to interminable meetings with no concrete decisions being made, and the coordination of the movement's loose territorial structure. GED members appreciate the secretary-general as a necessary tool to coordinate instances of dialogue 
with 'institutional actors', which include political parties, unions, and civic organizations from both the Basque Country and the international level, and trust the leading role of their intellectuals who set the course for new projects.

Consultations are entirely organized and funded by GED local groups or associations. Unlike formal membership in GED (through a small voluntary fee), local engagement is instead informal but very important on an interpersonal level, as any consultation must be carried out by local members. Each group observes similar principles (being autonomous, collaborative, and formed by people with different political sensibilities), although its composition varies according to the sociology of each town and the time of the consultation. While everyday work is generally assisted by adults and senior people who have more spare time, youths bring massive support for particular activities at designated times.

People who volunteer for GED often have trajectories within political parties, cultural associations, feminism, sports, and youth organizations. Most are Abertzales, ${ }^{6}$ that is, pro-independence from a socialist middle- or workingclass background. They refer to their country as Euskal Herria, ${ }^{7}$ which means 'Basque People' in the territorial and human sense, and share a frustration with government institutions and the political establishment, both at home and in Spain, for not being able to constructively address cleavages in a society traumatized by various cycles of political violence. Most members have experienced arrest, jail time, or being shot at, or they have friends and relatives who are incarcerated or have been exiled. Beyond a diversity of personal reasons, they often advance a common understanding of the value of collective action as the best way to peacefully achieve rights of self-determination. This means not so much breaking with Spain and France as becoming a society capable of deciding on its political options and coping with dissent. As far as I gathered in different locations, GED volunteers highlight the wish to break down the walls that for the last decades have kept them in silence while dealing with neglect, suspicion, and isolation. As in the 'game' of The Ring, they want to break with those ordinary elements of a survival technique to deal with "fear of the Spanish state, of ETA, of people from your village, your neighbor, your relative, and so on," one friend explained me.

To organize a local consultation requires at least a year or more of preparation. As part of a participatory process established in 2015 by the Idazkaritza, basic rules must be observed (some of which are provided for in a protocol), and documents must be produced. This process constitutes a guideline and a safeguard, rather than a mechanism to ensure standardization, and provides legality to prevent troubles such as monetary fines or eventually being arrested. Because most people never read them fully, there are many misunderstandings, usually solved by exegesis in informal meetings. Broadly speaking, the basic rules help to organize the process of a consultation. The first rule addresses functionality. It 
mandates the creation of a local group (an ad hoc association with a legal name, bank account, and insurance), which has to find a place to hold meetings and daily activities and which must produce its own economic resources to cover expenses and fund future activities. The second rule has to do with legitimacy. Volunteers must produce the social validity of the future consultation by collecting a minimum number of signatures, usually 10 percent of the local residents above the age of 16. Filling out the signature forms is an extremely artisanal and personalized work. Together with these rules, there is a third one concerning the question to be decided: it must emerge from a local consensus process that takes place at public venues such as cultural centers, theaters, and the like. ${ }^{8}$

Conflicts often arise during the consensus process because some groups prioritize having the most wide and welcoming question, while others prefer to give room to certain key words such as 'independence', 'republic', and 'sovereignty'. A woman from Bizkaia province explained to me: "In towns like mine, where there are lots of Spanish right-wingers, we ended up with the most innocuous, tame, and lukewarm question: 'Do you think that you have the right to decide about your future?' It's like saying, 'May I think?'” Voting, in turns, consists in marking YES, NO or Blank to such questions. Results are normally around 90 percent in favor of YES. The average participation oscillates from 17 percent in cities of more than 40,000 people, to 70 percent in small villages of less than $2,000 .^{9}$

Preparing a consultation is a full-time activity. The engagement is so hectic that it can take time away from family and friends, jobs and vacations, and can result in creative ways to combine militancy with simple leisure. I met various members who traveled to other cities to visit friends and relatives, carrying with them GED merchandising in the hope that that they could sell a shirt, a pin, or a calendar and thus contribute to the movement. I have seen senior members performing delicate acts of juggling in order to accommodate previous schedules of taking care of grandchildren with last-minute GED meetings. Although they say that they are tired, everybody happily sacrifices spare time for 'the cause'.

GED members experience joy as a general approach to sociality. The weekly meetings of local groups, the monthly regional gatherings, and every singular occasion of assemblage usually ends up with sharing a drink at a nearby tavern, where laughs, jokes, and mundane comments saturate the atmosphere. These experiences match with a general disposition toward being polite and humorous, exercising tolerance, welcoming differences, and training openness. At the same time, a joyful approach to activism balances out personal and collective discipline. I have witnessed how fever, a pain in the hips, a cancer treatment, or a fight with a boss or a partner did not stop GED members from fulfilling their commitments. Others noticed and responded: "Please go rest, I can take care of this." Being at a consultation table for eight hours, working at 
an information point under heavy rain, hanging posters on a cold night-the only remuneration for these activities is the pleasure of belonging to something bigger and more promising. Many senior members told me: "I might not see a referendum happening, but my grandchildren or perhaps my children might. That's enough." They trust that their dreams of another society and sovereignty are possible. A man who had served a jail sentence said to me: "Mankind creates the future, although no one is really sure when that future might start. One has to try."

The 'joy to decide' is both politically and socially transformative. According to the people I spoke with, it has had at least two main impacts in their lives. First, it has allowed Abertzales from different political affiliations and ideologies (leftists and right-wingers) to work together for a common cause. In some villages, Abertzales who had not spoken to each other for over 30 or 40 years have met and now share a table, meals, or a car ride, besides attending regular meetings. Some people confessed this to me in tears; others offered "proof" of these encounters, which had seemed "impossible." A man told me: "I have a socialist friend who was a member of the national Spanish government. [He] became so committed to the consultation that he not only signed that the voting was done correctly but also became the president of the guarantee commission!" Second, it has allowed a renewed sociality. Most members got to know and make friends with new people from different age groups, occupations, and social milieus. The fact that people who consider themselves 'independents' (from party politics) felt attracted to GED's platform, based upon achieving the RtD by peaceful and democratic means, opened the realm of independence-related activism. The consultation process has also attracted people from non-Basque backgrounds who had previously disregarded participating in Basque organizations or social movements, which were considered rather exclusive or exclusionary.

Another salient aspect of consultations is how GED evaluates their importance by breaking with the hegemonic eligibility regimes and auditing cultures of the state and the market. By placing the right to decide against the right to vote, GED defends the incommensurability of elections and consultations. When they are forced to discuss electoral figures, GED members point out that the average voter turnout in Spain is low, around 65 percent, while it is 60 percent in the Basque Country, so they should be proud for achieving a participation rate of 25 percent without any institutional resources. They wish to increase these figures to the point of having more people voting NO.

Yet GED has received severe criticism for its presentation of the RtD. Without necessarily questioning the movement, some academics and politicians nonetheless point to the ambiguity of its legal status. The RtD is sometimes introduced as a 'human right' in line with the 1985 UN Declaration; as a 'natural right' with regard to the capability and capacity to effect decision making and control over one's body; and as a 'pre-political' right that has affinity with the 
Basque paradigm of autoeraketak (personal and collective self-establishment). When questions such as "Who is entitled to decide for whom?" or "How is this right related to others?" arise, GED members often point to a hierarchy of political values between burujabetza (sovereignty) and erabakia (decision). They stress that while nationalism is associated with backward ethnic political discourses, the polysemic motto of the RtD is rather a new democratic approach to national independence based on the right to individual self-determination in favor of the political emancipation of peoples.

Meanwhile, Spanish media and people identified with unionist partiesfor example, the conservative Popular Party (PP), the Socialist Workers' Party (PSOE), and breakaways from PP with right-wing populist orientations, such as VOX and Ciudadanos-have often belittled both GED and the right to decide. They convey their skepticism through two interrelated avenues: a spurious style of communication and a blurred political strategy, asking whether GED should be less ambiguous in its messaging and condemn ETA more openly and firmly, or suggesting that its members are mimicking the Catalans to disguise their true aims. My GED interlocutors also told me that the Basque radical left initially dismissed the movement for being naive, inexperienced, and without a clear political program. This contradicts conventional wisdom that depicts GED as created and fostered by political parties.

Catalonian influence has often been acknowledged as crucial to the development of the RtD. Indeed, long before GED was officially launched, its founding members had been working hand in hand with Catalan independence campaigners, with whom they shared the struggle that eventually led to the Catalan process (Clua 2014). But GED members contest the idea of merely mimicking the Catalans, pointing to their cooperation and ideological affinities and to their own antecedents, notably the Ibarretxe plan. Submitted in 2002 by Juan José Ibarretxe (PNV, 1999-2009), the former president of the Basque Country, and approved by the Basque Parliament in 2004, the 'new political status' for the Basque Country was eventually rejected by the Spanish Parliament in 2005. The plan stated that Basques have the right to decide their own future and proposed a free association of the Basque Country with Spain-partially inspired by Northern Ireland's Good Friday Agreement (Keating and Bray 2006). ${ }^{10}$ A Catalan political scientist, who was an external observer with me on a consultation, clearly recognized this: "They [Basques] did it first! While the right to decide was included in the Ibarretxe plan, Catalonia staged it in 2006 within the Catalan sovereigntist process."

There is a sort of paradox about how the RtD has enabled new connections while surviving the backlash from conservative forces. On the one hand, the political majority in the Basque Country are Abertzale, and both left- and rightwing Abertzales have been supportive of replacing the old frame of self-determination. However, this has not been formally translated within the self-government 
Statute of Gernika-where "historical territorial" criteria, advocated by the current governing EAJ-PN, predominates. On the other hand, the lack of a single legal definition has been a key component of GED's sovereignty-in-practice, in which the joy of decision helps to overcome fear and the traumatic experiences of violence and repression. In other words, by merging at the everyday level, people can actually 'enjoy' sovereignty while achieving it, not by rule or by force but by prefiguring it within a wider experience of political pleasure.

In the next section I examine GED's everyday politics pivoting around saretzea, a form of sovereignty-in-practice that can be seen as prefigurative politics. This allows people to transform the negative memories of the past into something positive, producing a subjectivity that encourages them to enjoy politics and to perform sovereignty as a positive force.

\section{Political Pleasure and Saretzea}

Should GED members speak only Euskara if just 30 percent of the inhabitants are Basque speakers? I asked this to Jexus, one of the few 'liberated'11 members, who is in charge of ekimenak (public activities) to raise awareness and gain public attention. He was driving me from Donostia to Mondragón/Arrasate to attend the weekly meeting of the General-Secretariat, which has its headquarters in the same place where the Basque cooperative movement was born in the 1950s.

Jexus avoided answering my question with a smirk. Instead, he offered me generous descriptions about the events considered the cornerstone of the movement. The first in 2014 was a 123-kilometers giza katea (human chain) from Durango to Iruña/Pamplona in support of self-determination. They expected 50,000 people to cover the distance, but eventually 150,000 took part. A year later they organized simultaneous performances in the main Basque football stadiums that consisted of sewing pieces of fabric with messages printed on them ('the people's will') in huge ballot boxes; this event was not so successful, and GED’s bank account ended overdrawn. Between 2006 and 2018, its members focused on the popular consultations and produced smaller events. The last big performance, which eventually took place on 10 June 2018, consisted of a 202-kilometer human chain linking the three capital cities of Euskadi. This was the biggest demonstration held in the Basque Country. It began in Donostia's boulevard and ended at the gates of the Basque Parliament in Vitoria-Gasteiz, where they presented the document Herri-ituna (The People/Citizens' Agreement). Along with these major events full of political symbolism (flags, banners, songs, shirts, etc.), hundreds of smaller ones, such as community talks, conferences, workshops, and popular meals, were organized.

Upon arrival at Mondragón, my gentle driver paused our animated conversation to warn me: "You have to understand that what GED actually does is 
not translatable into Spanish: saretu, saretzea, this is what we do." I replied: "Networking?" (for sare is a net). "Well sort of, but it's more than that. We have been looking for a word, but none does it justice." The term was utilized several times at the three-hour meeting, for example, when Zelai, GED's spokeswoman, offered a detailed list of people and institutions ready for an upcoming joint demonstration in Bilbao; when Karmele, the then secretary, showed a PowerPoint presentation of the 2018 schedule; and during the subsequent poteo at a tavern, where drinks were shared in such a communal manner that it was mandatory not to keep track of who paid for the rounds.

Within GED not everybody is fluent in Euskara, but all of them are Euskaltzailes (those who love/take care of Euskara). ${ }^{12}$ They often engage in intense debates about words and expressions. I witnessed a two-hour discussion about whether anitz could be translated as 'a lot', 'many', or 'endless'. A prominent scholar who specializes in comparative nationalisms (Irish/Basque) warned me: "You won't understand Basque politics until you read their intellectuals in their own language." I am aware that the "ontological gap between words and social processes ... cannot be bridged from within the language itself" (Hastrup 1995: 27). However, I searched saretzea in various dictionaries. It turned out, as expected, to be the nominalization of the adverb saretu. According to an Elhuyar dictionary, saretu means (1) to fray, to wear out (sare-itxura hartu: to take a net/network form/appearance), or (2) to mend, to darn (pasaratu: darned clothes). Euskara differentiates between transitive and intransitive verbs; saretzea could be both.

Trapped into 'networking', I began to ask to my friends if they could help me with the meaning of saretzea. In general, their conclusion was: "It's untranslatable.” A couple of exceptions were a politician and writer who suggested that I explore amarauna, the spider web, “which gives a better idea of something fragile, slow, and artisanal but at the same time less capillary, stronger, more lasting and abiding." The other was Miren, a philologist herself and the niece of an important Basque linguist, who is known among GED members for using a refined Euskara. We met various times and eventually agreed that 'socializing' was appropriate enough since saretzea implies a form of sociality. But a few weeks later she sent me an e-mail expressing doubts: "I thought again and spoke to a friend. Socializing is gizarteratu while saretu is interweaving." She ended up advising me to forget translations and instead use an explanation of the term: "the way to establish certain relationships in the form of a web." Her explanation was telling: "Because while you can do saretu in a good manner, socializing also can be done badly, when social fabric breaks or is weak, or when there is no empathy in the sense that there is no community."13

The futile word-finding enterprise helped me to revisit situations I had not connected with saretzea in the first place, for instance, when people would avoid phoning someone due to not enough familiarity ("I can’t just say, 'Hello, 
I'm calling from GED to invite you to a meeting'!") or when my research participants discussed who would contact whom, producing endless lists during several of the weekly meetings. I remembered that one day I teased a friend about those confusing lists, and he replied: "Someone contacts someone they know. It's not like harremanak [making relationships]. It's about building up something bigger and stronger that can be activated at any time." I also realized that popular consultations are the archetype of saretzea. A young man explained GED through local geographical landmarks: "If Jon wants to climb the Txindoki mountain and I want to go to the village of Abaltzisketa, we can share a big part of the stretch together up to the point where the path bifurcates." This processual disposition is often repeated in GED slogans about collective action: pausoz-pauso, step by step. Actually, GED's 'sociopolitics' (Ssorin-Chaikov 2015) is also saretzea. As in the socializing and the spider web examples, doing saretzea serves as a kind of political action that is simultaneously strong and fragile: it opens up the horizon of potential members and collaborators, but also imposes limitations of trust; it fosters plurality yet curtails its scope. Yet based on the experience of both joy and fear, it unites negative experiences from the past with positive signs toward the future.

Considering GED's sovereignty-in-practice, the conceptual scope of saretzea can be categorized as 'prefigurative politics'-in other words, living politics as a constituent activity that is regarded as positive, constructive, and innovative (Graeber 2007; Ibrahim and Roberts 2018). It has to do with the collective production of alternative subjectivities, and it encourages a critical reconceptualization of politics beyond the unifying space of the political parties and ideologies of democracy formally identical with the nation-state. This activity is the opposite of the representational politics of waiting for opportunities brought about by others to make decisions on one's behalf. In this sense, when a popular consultation is held, doing saretzea activates the RtD in a way that it becomes already achieved. But this seeming zero point from which the political order can be constituted is actually about the labors of producing such conditions. I believe that the extensive use of geographical metaphors in GED public discourses (climbing a mountain, biking, navigating the seas) holds a particular meaning through saretzea: crucial decision-scapes are shaped by a forward-moving sociality. ${ }^{14}$

This is why saretzea is not mere networking. Rather, GED shapes past and potential fears of repression into possibilities of enjoyment that I would like to call possibilities of 'political pleasure'. By political pleasure I understand an affective disposition toward political work that arises from enjoyment of the collective praxis of producing transformative projects. Stemming from the recognition that "imagination and creativity are always the ultimate source of power" (Graeber 2009: 505), it aims to capture the commitment to expressing political emotions and finding pleasure and sustenance by engaging in 
transformative projects. Unlike the hedonist individual pleasure advocated by consumerism and the kind of political experiences fostered by institutional representation, it is founded on the practical acknowledgment that being part of something bigger is as much encouraging as pursuing common goals despite dissent. Political pleasure fills people with a sense of possibility. It is based not only on joy but on many other emotions, such as frustration, boredom, sacrifice, outrage, animosity, and betrayal. In this regard, saretzea is both the means and outcome of such politics. It belongs to a transformational praxis (Lazar 2017) that connects political goals such as the RtD with emotions such as joy in a way that enables an actual sociality of sovereignty-in-practice. In sum, although saretzea does not erode the potential of violence associated with sovereignty, it does encourage political pleasure-both extrinsic and intrinsic. Unlike violence, which is ontologically destabilizing because it can turn routine events-from sharing a phone number to speaking Euskara-into fear, saretzea embodies the work of 'refiguration'. GED members feel pleasure in their politics, and that is what they want to performatively bring into existence.

\section{Conclusion}

In this article I have described the emergence of Gure Esku Dago in the Basque Country within a wider politics of the differences between popular sovereignty, self-determination, and secessionism that triggers an important change of paradigm in Basque politics - and one of wider relevance to the anthropological study of sovereignty. GED is a prefigurative social movement that anticipates the Basque People's Right to Decide through a range of events and strategies, from assemblies to popular consultations, fostering popular sovereignty and self-determination claims of democratic and progressive politics. This approach to Basque independence informs a sovereignty-in-practice that breaks with the long-standing association between the desire for statehood and violence in the region. GED creates an environment in which producing subjectivities that enjoy politics and perform sovereignty as a positive force is possible.

The actual exercise of sovereignty pivots around violence-exercised in the bodies, territories, and imaginations. But it does not follow that every sovereign project is violent. Can people produce spaces for joyful politics that do not reproduce the basic mechanisms of sovereign violence and even seek to challenge it? Can we speak of 'sovereignty as joy' even when sovereign projects are tributaries of experiences of violence and repression? The prefigurative politics of GED seems to make such a case: its joyful sovereignty-in-practice, which is both politically and socially transformative, allows us to speak of political pleasure.

GED's case brings forward the necessity of questioning certain analytics of the politics of sovereignty that see them as Schmittean claims. It also opens 
up a reflection on the limits of the paradoxical logic of sovereignty by which any legal political order can only be created by some force to which that legality does not apply. Joy is only one aspect among others of a complex political arena that includes fear and trauma; however, it is an aspect that has often been neglected. A joyful sovereignty-in-practice within prefigurative politics could inform a theory of political action whereby self-determination can be reimagined as a right to decide 'from within' versus 'on behalf of'. Of course, the underlying question is, what kind of politics could such sovereignty materialize within a context where an independent Basque state seems unviable and a future referendum risks being cast as illegal? But this question rather speaks of our own political imaginations concerning sovereignty, including the uneatable hyphen between the state and the nation. I would like to think that this is GED's anthropologically 'uncomfortable' value that Raymond Firth wished for the discipline to consider (Bear 2017: 142).

GED affords Basque people a chance of remaking themselves into political subjects, breaking the cycle of violence and state desire. Fighting for the $\mathrm{RtD}$ means to experience the tension between an unattainable ideal, with its embodied realities, and a 'state of exception', of being part of a community and standing outside of it at the same time. The response of most observers of Basque politics, just like anthropologists of sovereignty everywhere, is resignation and despair. What I have outlined here, however, is that it is possible to confront the same tensions joyfully. Basque activists give an example of how to prefigure a different kind of politics, and anthropologists would do well to learn from it.

\section{Acknowledgments}

An external CONICET grant funded this project. I would like to thank GED members for their inspiring insights and kindness. I am particularly grateful to the anonymous reviewers and the journal's editors for their helpful and generous comments and their suggestions for refining my arguments. I am responsible for any remaining shortcomings. 
Julieta Gaztañaga (PhD, MSc, BA) is a specialist in the political anthropology of Argentina and the Basque Country. She is a Researcher at CONICET and an Associate Professor in the Department of Anthropology, University of Buenos Aires. She has carried out extensive ethnographic fieldwork in various provinces of Argentina and southern Brazil, focusing on electoral processes, Peronism, public works and road infrastructure, integration processes, and federalism. Her current research is about social movements in the Basque Country, in fields that include self-determination claims, sovereignty, political imagination, and nationalism. E-mail: julieta.gaztanaga@conicet.gov.ar

\section{Notes}

1. Marked by divisions of origin, attachment to the language, political affiliation, class, and locality, Basque nationalism has diverse strands. For example, the Foral tradition, based on historic rights, emphasizes limited sovereignty and negotiation, while the national and social liberation ideology of separatism is based on alternative sovereignty (Gurrutxaga 1996).

2. Greater fiscal autonomy, an independent police force and education system, and a functioning welfare state partly explain why there is less support for independence in the Basque Country when compared with Catalonia (Martinez Riera and Zubiaga 2014).

3. The 'sovereign turn' (Bonilla 2017) produced a proliferation of conceptual terms to describe sovereignty, such as 'fractured' (Ong 2006), 'interdependent' (Cattelino 2008), 'aleatory' (Dunn and Cons 2014), and 'narco' (van Dun 2014), along with variants such as 'emergent', 'nested', 'criminal', and 'fictive'.

4. Some elements for a different approach to sovereignty where violence is not an essential nature of society but of a certain form of political power with cosmic pretensions can be found in the links between the 'divine' or 'sacred' kingship and cosmologies of temporality, alterity, and utopia (Graeber and Sahlins 2017). Ethnographic analysis following this approach questions the legalistic and Cartesian frameworks of (post-)colonial modernity, for instance, when examining de facto states of armed groups and considering communities of care, emerging social relations, and subject positions rather than governance control and legitimacy (Ong and Steinmüller 2021).

5. See GED's website at https://gureesku.eus/zer-da-gure-esku/\#laburpena.

6. A neologism for patriot, Abertzale was coined in the nineteenth century by S. Arana Goiri, the founder of Basque nationalism. The Abertzale political divide includes various positions from left to right wing, although it is often employed to designate those on the radical left who support independence.

7. Euskal Herria as a whole is divided in two national regions-Iparralde, the northern part, and Hegoalde, the southern-and seven political administrative units: four in the French Pyrénées-Atlantiques department; three in the 
Spanish Basque Autonomous Community (CAV), and the Chartered Community of Navarre.

8. Questions (in Spanish and Euskara) are variations of the following one: "Nahi al duzu euskal estatu burujabe bateko herritar izan?" (Do you want to be a citizen of a sovereign Basque state?).

9. GED uses the public electoral census but has produced its own accreditation electronic database, legalized by notaries to guarantee that people cannot vote more than once.

10. After its constitutional rejection, Ibarretxe proposed a referendum in 2008 that was ultimately abandoned due to the re-escalation of the armed conflict. Some antecedents are the 1996 Pact of Lizarra, which demanded more selfgovernment, and the 1998 declaration of Lizarra-Garazi, in which Abertzale parties called for self-determination rights (Gaztañaga 2020).

11. This is common Spanish terminology among political parties and labor unions for people who are fully committed to 'serve the cause' and hence free themselves by working a day job. Their salaries are lower, and they have to work more hours than before, but they feel happier.

12. According to the 2016 socio-linguistic survey, 33.9 percent of people aged 16 and above are fluent Euskara speakers, 19.1 percent are passive speakers, and 47 percent speak only Spanish. The vast majority of Basque speakers live in Gipuzkoa. See https://www.euskara.euskadi.eus/r59-738/es/contenidos/ informacion/argitalpenak/es_6092/encuestas_sociolinguisticas.html.

13. The untranslatable nature of saretzea is telling considering Basque nationalism stereotypes within rueful self-recognition (Herzfeld 1997) or, even worse, a Basque's version of Deleuzian rhizome as simply a euphemism of an otherwise clandestine shadowy activity, that is, a guerrilla war strategy customized to the post-ETA scenario. At the same time, approaching saretzea with the available repertoire of the reconfigured anthropology of sovereignty would reinforce the depressing version of totalitarian politics. This, for instance, would imply that the very action of asserting that saretzea is not translatable is an act of sovereign violence. Or, in a softer version, that saretzea is but the domain of trauma and fantasy (Aretxaga 1997: 231), and that sovereignty can only be found through biopower. Framing it within GED's ritualized actions, saretzea is closer to the communities of joy described by Edith Turner (2012).

14. From a Gramscian perspective, GED seeks to affect the existing hegemonic relationships in Basque-Spanish politics. Advancing the RtD through saretzea goes beyond symbolic voting; it is instead a philosophy of praxis based on the democratic socialization of a new paradigm of sovereignty. Among the two methods for challenging hegemony conceived within a continuum by Gramsci ([1975] 2007: 168), GED trusts a "war of position" rather than a "war of maneuver" for creating alternative institutions and intellectual resources. In the sense of establishing the conditions to imagine changes as feasible, this enables the development of a strong democratic culture prior to reaching independence. 


\section{References}

Agamben, Giorgio . 1998. Homo Sacer: Sovereign Power and Bare Life. Trans. Daniel Heller-Roazen. Stanford, CA: Stanford University Press.

Aretxaga, Begoña. 1988. Los funerales en el nacionalismo radical vasco [Funerals in radical Basque nationalism]. Donostia: Baroja.

Aretxaga, Begoña. 1997. Shattering Silence: Women, Nationalism, and Political Subjectivity in Northern Ireland. Princeton, NJ: Princeton University Press.

Aretxaga, Begoña. 2003. "Maddening States.” Annual Review of Anthropology 32: 393-410.

Aretxaga, Begoña. 2005. States of Terror: Begoña Aretxaga's Essays. Ed. Joseba Zulaika. Reno: University of Nevada Press.

Bear, Laura. 2017. "Anthropological Futures: For a Critical Political Economy of Capitalist Time.” Social Anthropology 25 (2): 142-158. https://doi. org/10.1111/1469-8676.12412.

Benjamin, Walter. 1978. “Critique of Violence.” In Reflections: Essays, Aphorisms, Autobiographical Writings. Ed. Peter Demetz; trans. Edmund Jephcott, 277300. New York: Harcourt Brace Jovanovich.

Bonilla, Yarimar. 2017. “Unsettling Sovereignty.” Cultural Anthropology 32 (3): 330-339. https://doi.org/10.14506/ca32.3.02.

Cattelino, Jessica R. 2008. High Stakes: Florida Seminole Gaming and Sovereignty. Durham, NC: Duke University Press.

Clua, Montserrat. 2014. "Identidad y política en Cataluña: El auge del independentismo en el nacionalismo catalán actual” [Identity and politics in Catalonia: The rise of independentism in contemporary Catalonian nationalism]. Quaderns-e de l'Institut Català d'Antropologia 19 (2): 79-99.

Comaroff, Jean, and John L. Comaroff. 2016. The Truth about Crime: Sovereignty, Knowledge, Social Order. Chicago: University of Chicago Press.

Douglass, William A., ed. 1985. Basque Politics: A Case Study in Ethnic Nationalism. Reno: University of Nevada Press.

Dunn, Elizabeth Cullen, and Jason Cons. 2014. "Aleatory Sovereignty and the Rule of Sensitive Spaces.” Antipode 46 (1): 92-109. https://doi.org/10.1111/ anti.12028.

Elorza, Antonio. 2001. Un pueblo escogido [A chosen people]. Barcelona: Crítica.

Fassin, Didier, and Mariella Pandolfi, eds. 2010. Contemporary States of Emergency: The Politics of Military and Humanitarian Intervention. Brooklyn, NY: Zone Books.

Foucault, Michel. 2003. "Society Must Be Defended": Lectures at the College de France, 1975-76. Ed. Mauro Bertani and Alessandro Fontana; trans. David Macey. New York: Picador.

Gaztañaga, Julieta. 2020. "No son los monstruos, es la violencia: Una etnografía del soberanismo vasco para garantizar vidas que merecen ser vividas" [It is not about monsters, it is the violence: An ethnography of Basque sovereignty as a tool to guarantee lives that deserve to be lived]. Cuadernos de antropología social 51: 153-168. https://doi.org/10.34096/cas.i51.8238. 
Graeber, David. 2007. Possibilities: Essays on Hierarchy, Rebellion, and Desire. Oakland, CA: AK Press.

Graeber, David. 2009. Direct Action: An Ethnography. Oakland, CA: AK Press. Graeber, David, and Marshall Sahlins. 2017. On Kings. Chicago: HAU Books. Gramsci, Antonio. 1972. Los intelectuales y la organización de la cultura [Intellectuals and the organization of culture]. Buenos Aires: Nueva Visión.

Gramsci, Antonio. (1975) 2007. Prison Notebooks, Volume 3. Ed. and trans. Joseph A. Buttigieg. New York: Columbia University Press.

Gurrutxaga, Ander. 1996. Transformación del nacionalismo vasco: Del PNV a ETA [Transformation of Basque nationalism: From PNV to ETA]. San Sebastián: Aramburu.

Hansen, Thomas Blom, and Finn Stepputat, eds. 2005. Sovereign Bodies: Citizens, Migrants, and States in the Postcolonial World. Princeton, NJ: Princeton University Press.

Hansen, Thomas Blom, and Finn Stepputat. 2006. "Sovereignty Revisited." Annual Review of Anthropology 35: 295-315. https://doi.org/10.1146/annurev. anthro.35.081705.123317.

Hardt, Michael, and Antonio Negri. 2004. Multitude: War and Democracy in the Age of Empire. New York: Penguin Press.

Hastrup, Kirsten. 1995. A Passage to Anthropology: Between Experience and Theory. London: Routledge.

Herzfeld, Michael. 1991. A Place in History: Social and Monumental Time in a Cretan Town. Princeton, NJ: Princeton University Press.

Herzfeld, Michael. 1997. Cultural Intimacy: Social Poetics in the Nation-State. New York: Routledge.

Humphrey, Caroline. 2004. "Sovereignty.” In A Companion to the Anthropology of Politics, ed. David Nugent and Joan Vincent, 418-436. Malden, MA: Blackwell.

Ibarra, Pedro. 2005. Nacionalismo: Razón y pasión [Nationalism: Reason and passion] Barcelona: Ariel.

Ibrahim, Joseph, and John Michael Roberts. 2018. “Lenin’s Lens: The Occupy Movement, an Infantile Disorder?” Journal of Cultural Analysis and Social Change 3 (1): 1-11. https://bura.brunel.ac.uk/bitstream/2438/20012/1/FullText.pdf.

Juaristi, Jon. 1987. El linaje de Aitor [Aitor's lineage]. Madrid: Taurus.

Kauanui, J. Kēhaulani. 2017. “Sovereignty: An Introduction.” Cultural Anthropology 32 (3): 323-329. https://doi.org/10.14506/ca32.3.01.

Keating, Michael, and Zoe Bray. 2006. "Renegotiating Sovereignty: Basque Nationalism and the Rise and Fall of the Ibarretxe Plan.” Ethnopolitics 5 (4): 347-364. https://doi.org/10.1080/17449050600865503.

Laclau, Ernesto. 2008. Debates y combates: Por un nuevo horizonte de la política [Debates and combats: For a new horizon of politics]. Buenos Aires: FCE.

Lazar, Sian. 2017. The Social Life of Politics: Ethics, Kinship, and Union Activism in Argentina. Stanford, CA: Stanford University Press.

Martinez Riera, Meritxell, and Mario Zubiaga. 2014. "Nation and State Building as Collective Action: A Comparative Analysis of Mechanisms and Processes in Catalonia and the Basque Country.” Anuari del Conflicte Social 4: 320-355. 
Moral, Félix. 1998. Identidad regional y nacionalismo en el Estado de las autonomías [Regional identity and nationalism in the State of Autonomies]. Madrid: Centro de Investigaciones Sociológicas.

Moreton-Robinson, Aileen, ed. 2007. Sovereign Subjects: Indigenous Sovereignty Matters. Sydney: Allen \& Unwin.

Ong, Aihwa. 2006. Neoliberalism as Exception: Mutations in Citizenship and Sovereignty. Durham, NC: Duke University Press.

Ong, Andrew, and Hans Steinmüller. 2021. "Communities of Care: Public Donations, Development Assistance, and Independent Philanthropy in the Wa State of Myanmar." Critique of Anthropology 41 (1): 65-87. https://doi. org/10.1177/0308275X20974099.

Rifkin, Mark. 2012. The Erotics of Sovereignty: Queer Native Writing in the Era of Self-Determination. Minneapolis: University of Minnesota Press.

Rodriguez Bornaetxea, Fito. 2011. Nacionalismo y educación: Teoría e historia de la educación en el País Vasco [Nationalism and education: Theory and history of education in the Basque Country]. Madrid: Delta Publicaciones Universitarias.

Ssorin-Chaikov, Nikolai. 2015. "Sociopolitics.” Reviews in Anthropology 44 (1): 5-27 https://doi.org/10.1080/00938157.2015.1001645.

Trouillot, Michel-Rolph. 2003. Global Transformations: Anthropology and the Modern World. New York: Palgrave Macmillan.

Turner, Edith. 2012. Communitas: The Anthropology of Collective Joy. New York: Palgrave Macmillan.

van Dun, Mirella. 2014. “Exploring Narco-Sovereignty/Violence: Analyzing Illegal Networks, Crime, Violence, and Legitimation in a Peruvian Cocaine Enclave (2003-2007)." Journal of Contemporary Ethnography 43 (4): 395-418. https:// doi.org/10.1177/0891241613520452.

Vilaregut, Ricard, Daniel Gómez, Pedro Ibarra, and Mario Zubiaga. 2014. La rebellió basca: Una història de l'Esquerra Abertzale [The Basque rebellion: A history of the Abertzale Left] Barcelona: Icaria/Pollen.

Zulaika, Joseba. 1996. Del Cromañón al carnaval: Los vascos como museo antropológico [From Cro-Magnon to carnival: The Basques as an anthropological museum]. Donostia: Erein.

Zulaika, Joseba. 2007. Polvo de ETA [ETA powder]. Irún: Alberdania.

Zulaika, Joseba, and William A. Douglass. 1996. Terror and Taboo: The Follies, Fables and Faces of Terrorism. New York: Routledge. 